\title{
Impact of Devaluation on Balance of Trade: A Context of Neighboring Countries
}

\author{
Usama Ehsan Khan *
}

\author{
Aamir Hussain Siddiqui ${ }^{\dagger}$ \\ Afshan Uroos ${ }^{\S}$
}

\author{
Muhammad Umar Zahid ${ }^{\ddagger}$
}

\begin{abstract}
Currency devaluation plays an important role in reshaping trade balance counties like China and Malaysia have experienced export-led growth based on maintenance of their devalued currencies. This study provides the effect of recent currency devaluation of Pakistan on its trade with neighboring countries namely China, India, and Iran. The countries are of remarkable importance because the trade climate of the region is in transition in the essence of China-Pakistan Economic Corridor (CPEC). The paper adopts the elasticity approach to test the effect of devaluation by examining Marshall-Lerner condition. The study uses Panel data estimation models to determine import and export elasticities which serve as inputs for MarshallLerner condition. The data of monthly frequency is analyzed over the period of January 2005 to May 2018. The empirical results show that Marshall-Lerner condition does not hold for Pakistan bilateral trade to China and India, however, fulfilled for Iran. It suggests that devaluation of December 2017 of PKR has improved the trade balance of Pakistan with Iran but deteriorated with India and China. The results of the study would allow us to understand the cost and benefits of regional trade integration.
\end{abstract}

Keywords: Intra-regional trade, devaluation, Marshall-Lerner, CPEC, balance of trade.

\section{Introduction}

Exchange rate adjustments is generally considered as a part of structural adjustment package to mitigate trade deficit. A change in exchange rate assumed to be having effects on imports and exports which are in the favor of balance of trade. A devaluation of currency will cause imports to be more expensive and exports to become cheaper thus discourage imports and encourage exports. Pakistan's existing exchange rate regime is "managed float" which was adopted in 1982 as a result of appreciation of US dollar in the international markets. The term "managed float" refers to a floating exchange rate where central bank occasionally intervenes to adjust the value of the currency to deal with external trade balance.

International trade has remained a key factor in upraising country's economic wealth and served as an engine to the economic growth of the world major economies. Pakistan's exports have been on declining path for the last few years. However, the country

\footnotetext{
* Research Associate at Trade Development Authority of Pakistan. Email: usama.ehsan@gmail.com

${ }^{\dagger}$ Assistant Professor, Applied Economics Research Center, Karachi.

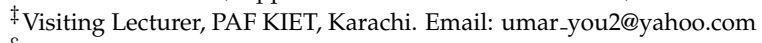

$\S$ Assistant Manager, Trade Development Authority of Pakistan.
} 
had shown good recovery in exports during 2013-14, when exports reached to the highest ever level to US\$ 25 billion. Despite that, in 2016-17, figure dropped to $22.5 \%$ and exports has declined to US\$20.4 billion. Pakistan's exports base is quite narrow, highly concentrated in a few commodities, namely, Textile and Clothing, Leather, Rice, Chemicals, Pharmaceuticals, and Sports goods. Similarly, Pakistan's export destinations are also limited, heavily concentrated among a few major trading partners, i.e. EU-27-top destination for Pakistan's exports having share of 34 percent, USA -second-largest market having share of 20 percent in 2016-17. On the other hand, imports have been increasing continuously as the domestic industry is not able to meet the domestic demand. Official figures released by Pakistan Bureau of Statistics (PBS) revealed that imports surged by $\$ 7.95$ billion while export improved by $\$ 3$ billion broadening trade deficit by $15.95 \%$. However, the import basket of Pakistan is heavily weighted by inelastic or less responsive. Even after the devaluation of rupees by $15.8 \%$ against US $\$$ has not brought any fruitful result.

Among neighboring countries, China has remained the 3rd largest export destination of Pakistan for the period of 2017-18. The exports to China were US\$ 1.7 billion and imports were US\$ 15.8 billion in 2017-18. Pakistan exports to India were US\$ 358 million and imports were 1.8 billion while the exports to Iran were US\$ 21 million and imports were US\$ 376 million for the same period. The Pakistan exports to China's registered growth of $14.7 \%$, while exports to Iran and India declined by 33\% and $0.29 \%$ respectively in 2017-18

Pakistan imported Electric Machinery and Equipment, Mechanical Appliances, Iron and Steel, Organic Chemical, Man Made filaments etc from China. Pakistan \& China is developing regional connectivity through Pakistan China Economic Corridor (CPEC). The imports of the country from China increased from US\$ 12 billion in 2015-16 to US\$ 15 billion in 2017-18 due to the imports of machinery for the CPEC. The imports became price inelastic due to the said extensive infrastructure project. Pakistan mainly imports Cotton, Organic Chemicals, Plastic, Machinery, Tanning and Dyeing extracts and Rubber articles from India. The imports appeared price inelastic from India as it may not improve trade balance by devaluing our currency.

However,the balance of payment is one of the key issue of Pakistan. The country is facing its highest level of BoP deficit. To overcome this problem, the country has taken the measures of currency devaluation several times.

The economic theories argue that the currency devaluation may help to improve the trade balance if the export and import baskets are elastic. It affects the trade balance through price and volume. One explanation of the phenomenon is that as currency devaluation makes imports expensive. On the other hand, domestic goods would become cheaper in the international market and exports can be increased. Both these effects are conditional primarily on the relative elasticity of exports and imports. The J-curve approach however argue that the merits are visible only in the long run even baskets are highly elastic and was supported by Dornbusch, Krugman, and Cooper (1976).

Mahmud, Ullah, and Yucel (2004) argue that Marshall-Lerner condition is more likely to be satisfied for countries with fixed exchange rate regime. The current study addresses the effects of devaluation of Pakistani rupee of December 2017 on imports and exports of Pakistan. It focuses only on three border-sharing countries of Pakistan i.e. India, China, 
and Iran. It first determines the imports and exports elasticities and domestic or global factors in determining the bilateral trade. The movements in trade balance and relative responsiveness of imports and exports baskets are then assessed by Marshall-Lerner conditions. The results of the study reveal that Marshall-Lerner condition is only satisfied for Pakistan trade with Iran but the conditions have not been satisfied in the case of China and India. Therefore, the devaluation of the currency improves the trade balance in the context of trade with Iran but depresses the trade balance further for the bilateral trade with India and China. The potential reason might be the fact that import basket of Pakistan from China is heavily billed by inelastic goods related to CPEC. While the imports from India is comprised of food items and since the Pakistan exports to these countries are less than imports therefore effects of inelasticity of imports in worsening trade balance dominates any relieve of trade balance contributed by exports.

\section{Literature Review}

Different exchange rate regimes have been implemented to different countries. The developing countries generally adopt some form of fixed exchange rate regime so as to encounter frequent movements in exchange rates. This section aims to discuss the existing literature in the context of exchange rate in relation with international trade.

Boyd, Caporale, and Smith (2001) via Vector Autoregressive Distributed Lag model found that the real devaluation improves the balance of trade after a lag because of J-curve effect in the context of OECD countries. Türkay (2014) found the similar evidence that the devaluation has pleasant effect on trade balance. It uses Marshall-Lerner condition to examine the elasticity approach of currency devaluation and trade balances. Mahmud et al. (2004) applied non-parametric kernel estimation technique on six developed countries. Export-import elasticities were calculated to check Marshal Lerner condition for said countries. Krueger (1983) analyzed that at the time of devaluation, the goods, which purchased or ordered, follow old contractual obligations. Jamilov (2013) investigates bilateral trade model in case of Azerbaijan with Europe, which is the major trading partner of Azerbaijan. The study analyzed that the depreciation in Azerbaijan decreased trade balance in the short run while improved in the long run. Caporale, Gil-Alana, and Mudida (2015) used quarterly data to test Marshall-Lerner condition for Kenya. They used export-import ratio, relative incomes, real exchange rates, applied co-integration and fractional integration methods and found that Marshall-Lerner condition is satisfied in the case of Kenya.

The literature is also rich in analyzing exchange rate movements and direction of trade in the context of Pakistan. Hasan and Khan (1994) found the effect of devaluation on Pakistan's trade balance by using quarterly data of general price level, export and import equation. They tested empirical model to satisfy Marshall-Lerner condition. The result shows that devaluation improved trade balance and satisfy Marshall-Lerner condition in Pakistan. Khan and Aftab (1995) estimated export-import demand function by using quarterly data and applied conventional method in the case of Pakistan. The study used real effective exchange rate instead of relative prices and found that no significant im- 
pact noticed on trade balance through devaluation. Akhtar and Malik (2000) estimates the effect of real devaluation, export incentives, inflation and real income by using quarterly data on the performance of Pakistan's trade with its top exporting partners. The study found that Germany and USA have strong income impact on Pakistan's trade performance while USA and Japan have export demand elasticity. Aftab (2002) applied OLS and 2SLS techniques to re-estimate trade elasticity in long run and existence of MarshallLerner condition and short run dynamics of exchange rate. The study used quarterly data for top ten trading partners of Pakistan.

Nawaz and Ghani (2018) established a negative relationship between devaluation and output growth for Pakistan, and Onakoya, Johnson, and Ajibola (2019) also found a negative relationship between devaluation and trade balance for Nigeria in the long run. Masih, Liu, and Pervaiz (2018) found no relationship between devaluation and trade balance for China. The indirect effect of devaluation is also seen empirically such as Olawole, Adebayo, and Idowu (2018) found negative impact of financial openness on economic growth for Nigeria, while Ali (2016) found a positive relationship between currency evaluation and interest rate for Pakistan.

\section{Data and Methodology}

The data for three neighboring countries i.e. Iran, India, and China is collected over the period of January 2005 to May 2018. Among neighboring (border-sharing) countries, Afghanistan is dropped because of data limitations.

The panel data estimation technique is applied in this study. The cross-sectional units in this study are Iran, India, and China which are observed over the period of July 2003 to February 2017. Following Shahzad, Nafees, and Farid (2017), the study has used fixed effect model for the model depicted in equation (1) below and random effect model for model in equation (2). The decision to use FEM and REM is on the behalf of Hausman Specification test.

The countries are expected to their own cultural diversity, distances and many other factors that are generally time invariant, therefore, fixed effect panel data model is appropriate over here. The modelling of elasticity has done by means of panel data regression. Mathematical depiction of the equations is given below:

$$
\begin{aligned}
& \log \left(\text { Pak }_{\text {Exports }}\right)_{i t}=\alpha_{0}+\alpha_{1} \log (R P X)_{i t}+\operatorname{alpha}_{2} \log \left(\text { Pak }_{\text {exrate }}\right)_{i t}+\alpha_{3} \log \\
& (\text { Partner_Ex_rate })_{i t}+\alpha_{4} \log \left(P a k_{-} I M\right)_{i t}+\alpha_{5} d \_i n d * \log (R P X)_{i t}+\alpha_{6} d_{\text {iran }} * \log (R P X)_{i t} \\
& +\alpha_{7} d_{-} F T A_{-} i+\alpha_{8} d_{-} D e c 2017_{t}+u_{i t} \\
& \log \left(P a k_{\text {Imports }}\right)_{i t}=\beta_{0}+\beta_{1} \log (R P X)_{i t}+\beta_{2} \log \left(\text { Pak }_{\text {exrate }}\right)_{i t}+\beta_{3} \log (\text { Partner_Ex_rate })_{i t} \\
& +\beta_{4} \log \left(P a k_{-} I M\right)_{i t}+\beta_{5} d_{\_} i n d * \log (R P X)_{i t}+\beta_{6} d_{i r a n} * \log (R P X)_{i t}+\beta_{7} d_{-} F T A_{-} i+ \\
& \beta_{8} d_{-} D e c 2017_{t}+u_{i t}
\end{aligned}
$$


Where,

' $\log ^{\prime}$ is the natural logarithm. 'Pak_Exports' is the exports of Pakistan (USD thousands) to ith country. 'Pak_Imports' is the imports of Pakistan (USD thousands) from ith country. 'Partner_CPI' is the consumer price index of the ith country. 'Partner_Ex_rate' is the exchange rate of ith country per USD. 'Pak_Ex_rate' is the exchange rate of Pakistan per USD; RPX is the relative prices of exports (export price index with base period January 2005 / World Manufacturing Index); RPI is the relative price index of imports (import price index with base period January 2005/ World Manufacturing Index); 'Pak_IM' is the Pakistan Industrial Manufacturing.

The dummy variables include 'd_FTA' takes value 1 for the country having FTA with Pakistan 0, 'd Ind' takes value 1 for India otherwise 0 ; 'd_Iran' takes vale 1 for Iran otherwise 0, and 'd_Dec2017' takes value 1 for the period after December 2017 (the month of currency devaluation).

\section{Marshall-Lerner Condition}

The Marshall-Lerner condition is named after Alfred Marshall (1924) and Abba Lerner (1985). The approach suggests that if the condition is satisfied then any devaluation in the currency will improve trade balance. Depreciation of the domestic currency will make imports more expensive and exports become cheaper in foreign currency terms. Imports are billed in a foreign currency, the domestic currency price of imports rises as the domestic currency depreciates, while the induced reduction in the quantity of imports decreases import expenditures. However, it is not the quantity that improves the trade balance but the total value of exports and imports that must change in order to affect the trade deficit. Therefore, elasticity of imports and export demand would determine the overall effect.

The generalized Marshall-Lerner index condition is as follows:

$$
W_{x} \epsilon_{x}+W_{M}\left(\epsilon_{M}-1\right)>0
$$

Where,

$\epsilon_{x}$ price elasticity of export.

$\epsilon_{M}$ price elasticity of import.

$W_{x}$ and $W_{M}$ are relative weights.

Note that $\mathrm{Wx}$ and $W_{M}$ are the shares of exports and imports respectively, in total trade i.e. imports + exports. It implies that $\left(W_{x}+W_{M}\right)=1$.

\section{Empirical Results}

This section describes results of the applied model in this analysis. The table-I and II corresponds estimates of equation (1) and (2).

The results depicted in table- 1 below revealed that a rise of $1 \%$ of exports to China will increase the exports by 0.4 percent, keeping the other things constant. However, the elasticities of exports to India and Iran are significantly greater than that of China. For instance, a percent increase in relative price (RPX) of exports to India will, on average, 
raise the export value by $0.9(=0.4+0.5)$ percent, assuming ceteris paribus. Similarly, the coefficient of elasticity for exports to Iran is 0.862 . Moreover, a statistically significant coefficient of dummy variable (d_Dec2017) reflects that average Pakistan exports to neighboring countries is meaningfully different before and after in the month of December 2017.

Pakistan exports to the neighboring countries (India, Iran, and China only) is significantly affected by the exchange rate movements of both PKR against USD and partner's currency against USD. It is found unitary elastic which suggest that if PKR is devalued by one percent in an international market would improve the Pakistan's export with neighboring country. In contrast to this, any devaluation to the partner's exchange rate will weaken Pakistan's exports with that of particular country by 0.6 percent. Both these effects are in line with the economic theory as it argues that any devaluation of domestic currency would reduce the unit price of domestic product in the international because they can be bought with fewer dollars thus increase in exports is inevitable. On the contrary, a devaluation faced by partner's currency will lead to decline in Pakistan's exports to that country as the importers in partner country will have to pay more of domestic currency against the dollar thus weaken their purchasing power which in turn decreases the demand of Pakistan's exports (or Partner's import).

It is also evident from the results that Pakistan's exports is also significantly dependent on the industrial manufacturing as any increase in IM will increase Pakistan's exports by 0.3 percent.

The table- 2 below illustrates the result related to import model. A percent increase in relative import price will also increase the imports of Pakistan by China by 0.31 percent, assuming all other variable constant. However, import elasticities of Pakistan for both India and Iran are significantly different from China i.e. 0.742 for India and 0.977 for Iran. It can be inferred that the import basket of Pakistan from China is relatively less elastic, however, nearly unitary elastic for Iran. Moreover, Pakistan's exchange rate is positively and significantly related with imports. The coefficient suggests that on average, devaluation of PKR by a percent will increase Pakistan's import value from the neighboring countries undertaken by 0.43 percent, assuming ceteris paribus.

The industrial manufacturing index of Pakistan also turned out to be significant. A percent surge in IM will increase the imports of Pakistan by 0.89 percent suggesting the complementarity of imports in industrial manufacturing. The dummy for FTA and devaluation of PKR of December 2017 found out to be significant for import model. It suggests that imports from countries with FTA (i.e. China and Iran) are significantly greater than the country without FTA (i.e. India) by USD 1.09 (=antilog (0.09)) thousands. The dummy related to exchange rate valuation (d_Dec2017) indicates that Pakistan imports from the neighboring countries undertaken is statistically different by USD 1.09 thousands (=antilog (0.089)) on average. 
Table 1

Model corresponding equation (1)

Results of Exports model

\begin{tabular}{lc}
\hline Variables & Coefficients \\
\hline Intercept & $2.610^{*}$ \\
$\log ($ RPX $)$ & $0.405^{*}$ \\
$\log ($ Pak_Exrate $)$ & $0.998^{*}$ \\
$\log ($ Partner_exrate $)$ & $-0.623^{*}$ \\
$\log ($ Pak_IM $)$ & $0.302^{*}$ \\
d_Ind_RPX & $0.503^{*}$ \\
d_Iran_RPX & $0.457^{*}$ \\
d_FTA & - \\
d_Dec2017 & $-0.220^{*}$ \\
\hline Dependent Variable: $\log$ (Pak_Exports) \\
*Significant at $1 \%,{ }^{* *}$ Significant at 5\%, \\
*** Significant at $10 \%$
\end{tabular}

Table 2

Model corresponding equation (2)

Results of Imports model

\begin{tabular}{lc}
\hline Variables & Coefficients \\
\hline Intercept & $2.610^{*}$ \\
$\log ($ RPI $)$ & $0.314^{*}$ \\
$\log ($ Pak_Exrate $)$ & $0.428^{*}$ \\
$\log ($ Partner_exrate $)$ & $-0.606^{*}$ \\
$\log ($ Pak_IM $)$ & $0.886^{*}$ \\
d_Ind_RPI & $0.401^{*}$ \\
d_Iran_RPI & $0.663^{*}$ \\
d_FTA & $0.090^{* *}$ \\
d_Dec2017 & $-0.089^{* * *}$ \\
\hline Dependent Variable: $\log$ (Pak_Imports) \\
* Significant at $1 \%,{ }^{* *}$ Significant at $5 \%$, \\
*** Significant at $10 \%$
\end{tabular}

Table-3 is devoted to the results corresponding to equation (1) i.e. condition for MarshallLerner.

The next table illustrates the results of Marshall-Lerner Index for bilateral trade of Pakistan with China, India, and Iran. Since the condition is only satisfied for Iran so any devaluation would improve trade balance for Pakistan. While any devaluation would depress trade balance of Pakistan with India and China.

Since Marshall-Lerner condition is not satisfied in the case of Pakistan, which implies that any devaluation in the currency may not improve the trade balance. Alternatively, both import and export elasticities are less than one, which endorses the fact that one percent increases (decreases) in a price decreases (increases) quantity imports/exports by less than one percent. Overall the results showed a negative impact of currency devaluation on trade balance of Pakistan. 
Table 3

Variables related to Marshall-Lerner Index

\begin{tabular}{lcc}
\hline Variables of Marshall-Lerner & Estimates & Marshall-Lerner Index \\
\hline Pakistan bilateral trade with China & & -0.55 \\
\hline Relative import weights $(\mathrm{Wm}):$ & 0.878 & \\
Relative export weights $(\mathrm{Wx}):$ & 0.122 & \\
Price Elasticity of exports $\left(\epsilon_{x}\right)$ & 0.404 & \\
Price Elasticity of imports $\left(\epsilon_{M}\right)$ & 0.341 & -0.012 \\
\hline Pakistan bilateral trade with India & & \\
\hline Relative import weights $(\mathrm{Wm}):$ & 0.771 & \\
Relative export weights $(\mathrm{Wx}):$ & 0.228 & \\
Price Elasticity of exports $\left(\epsilon_{x}\right)$ & 0.908 & \\
Price Elasticity of imports $\left(\epsilon_{M}\right)$ & 0.742 & \\
\hline Pakistan bilateral trade with Iran & & \\
\hline Relative import weights $(\mathrm{Wm}):$ & 0.228 & \\
Relative export weights $(\mathrm{Wx}):$ & 0.771 & \\
Price Elasticity of exports $\left(\epsilon_{x}\right)$ & 0.862 & \\
Price Elasticity of imports $\left(\epsilon_{M}\right)$ & 0.977 & \\
\hline
\end{tabular}

Table 4

Hausman Specification test results (Model in equation: 1)

Correlated Random Effects - Hausman Specification Test Test cross-section random effects

Null Hypothesis Ho: difference in coefficients not systematic

\begin{tabular}{lcccc}
\hline Coefficients & $\begin{array}{c}\text { (b) } \\
\text { Fixed Effect }\end{array}$ & $\begin{array}{c}\text { (B) } \\
\text { Random Effect }\end{array}$ & (b-B) & sqrt(diag(V-b-V-B) \\
\hline RPX & 0.405 & 0.495 & -0.090 & \\
Pak_ex_rate & 0.998 & 0.764 & 0.234 & \\
Partner_ex_rate & -0.623 & -0.071 & -0.551 & 0.0568 \\
Pk_IM & 0.302 & 0.136 & 0.166 &
\end{tabular}

$\mathrm{b}=$ consistent under Ho and $\mathrm{Ha}$; $\mathrm{B}=$ inconsistent under Ha, efficient under Ho

$\mathrm{p}$-value $=0.000$

Table 5

Hausman Specification test results (Model in equation: 2)

Correlated Random Effects - Hausman Specification Test Test cross-section random effects

Null Hypothesis Ho: difference in coefficients not systematic

\begin{tabular}{lcccc}
\hline Coefficients & $\begin{array}{c}\text { (b) } \\
\text { Fixed Effect }\end{array}$ & $\begin{array}{c}\text { (B) } \\
\text { Random Effect }\end{array}$ & (b-B) & sqrt(diag(V-b-V-B) \\
\hline RPI & 0.359 & 0.314 & 0.045 & 0.014 \\
Pak_ex_rate & 0.348 & 0.426 & -0.079 & -0.025 \\
Partner_ex_rate & -0.423 & -0.606 & 0.183 & 0.062 \\
Pk_IM & 0.824 & 0.886 & -0.044 & 0.008 \\
b=consistent under Ho and Ha; B=inconsistent under Ha, efficient under Ho \\
p-value =0.289
\end{tabular}

\section{Conclusion}

Currently, Pakistan has managed floating exchange rate regime. Pakistan has adopted policy of devaluation several times since its inception to improve trade balance. The result of this analysis revealed that both export and import models are good-fitted. The 
impact of exchange rate of Pakistan is highly significant for both models, which means that any fluctuation in the exchange rate spills over its effect to the trade and thus overall economy. The central bank, therefore, should aggressively maintain exchange rate within the defined bands.

Existing literature is quite rich in examining the impact of devaluation of currency and its impact on trade flows where it has been done. This study aims to fill a gap in literature by examining Marshall-Lerner index in the context of Pakistan trade with three neighboring countries i.e. China, India, and Iran. The fixed and random effect models of panel data have been employed to estimate export and import elasticities respectively. The results further endorsed the significance of exchange rate of Pakistan and the partner's country against US dollar. Pakistan has Free Trade Agreement (FTA) with China and Iran. The effect of FTA found significant in terms of imports which implies that these FTA's are favoring the partner countries rather than Pakistan.

The currency devaluation of PKR of December 2017 worsens the trade balance of Pakistan with India and China. The relative inelastic nature of Pakistan's imports is heavily pronounced for China as compared to India. It is also apparent in the existing trade composition of Pakistan with the India and China. Pakistan generally imports food related products from India while capital goods accounts for the major share of imports from China in a wake of China-Pakistan Economic Corridor. As far as Iran is concerned, the trade balance has improved to some extent but the trade volume of Pakistan-Iran is only negligible. It is found that industrial manufacturing plays an important role in translation of Pakistan exports and imports.

The finding of this paper suggests that stereotypical policy of devaluation has no positive effect on the economy. The policy should be more towards promoting export sector so that would be able to earn more foreign exchange. 


\section{References}

Aftab, Z. (2002). The long-run and short-run impact of exchange rate devaluation on Pakistan's trade performance. The Pakistan Development Review, 41(3), 277-286.

Akhtar, S., \& Malik, F. (2000). Pakistan's trade performance vis-a-vis its major trading partners. The Pakistan Development Review, 39(1), 37-50.

Ali, S. (2016). How does interest rate effect exchange rate of Pakistan: Evidence of ARDL bound testing approach. Journal of Finance and Economics Research, 1(2), 119-133.

Boyd, D., Caporale, G. M., \& Smith, R. (2001). Real exchange rate effects on the balance of trade: Cointegration and the Marshall-Lerner condition. International Journal of Finance \& Economics, 6(3), 187-200.

Caporale, G. M., Gil-Alana, L. A., \& Mudida, R. (2015). Testing the m arshall-1 erner condition in k enya. South African Journal of Economics, 83(2), 253-268.

Dornbusch, R., Krugman, P., \& Cooper, R. N. (1976). Flexible exchange rates in the short run. Brookings Papers on Economic Activity, 1976(3), 537-584.

Hasan, M. A., \& Khan, A. H. (1994). Impact of devaluation on Pakistan's external trade: An econometric approach. The Pakistan Development Review, 33(4), 1205-1215.

Jamilov, R. (2013). J-Curve dynamics and the Marshall-Lerner condition: Evidence from Azerbaijan. Transition Studies Review, 19(3), 313-323.

Khan, S. R., \& Aftab, S. (1995). Devaluation and the balance of trade in Pakistan: A policy analysis. Sustainable Development Policy Institute.

Krueger, A. O. (1983). Trade and employment in developing countries. National Bureau of Economic Research, Inc.

Mahmud, S. F., Ullah, A., \& Yucel, E. M. (2004). Testing marshall-lerner condition: A non-parametric approach. Applied Economics Letters, 11(4), 231-236.

Masih, J., Liu, D., \& Pervaiz, J. (2018). The relationship between RMB exchange rate and Chinese trade balance: Evidence from a bootstrap rolling window approach. International Journal of Economics and Finance, 10(2), 35-47.

Nawaz, M., \& Ghani, E. (2018). Currency depreciation and output nexus: Evidence from Pakistan. Panoeconomicus, 65(2), 183-200.

Olawole, K. O., Adebayo, T. O., \& Idowu, O. S. (2018). Openness, government size and economic growth in nigeria. Journal of Finance and Economics Research, 3(1), 71-84.

Onakoya, A. B., Johnson, S. B., \& Ajibola, O. J. (2019). Exchange rate and trade balance: The case for J-curve Effect in Nigeria. KIU Journal of Social Sciences, 4(4), 47-63.

Shahzad, A. A., Nafees, B., \& Farid, N. (2017). Marshall-Lerner condition for South Asia: A panel study analysis. Pakistan Journal of Commerce and Social Sciences, 11(2), 559575.

Türkay, H. (2014). The validity of Marshall-Lerner condition in Turkey: A cointegration approach. Theoretical \& Applied Economics, 21(10), 21-32. 